\title{
The role of positron emission tomography for evaluation of lung nodules and staging lung cancer
}

\author{
Barbara M. Fischer • Jann Mortensen
}

Published online: 15 January 2012

(C) Springer Science+Business Media, LLC 2012

\begin{abstract}
Positron emission tomography with computed tomography (PET/CT) and the clinical use of this imaging technology has developed rapidly during the last decade, especially in the field of lung cancer. This review includes a brief introduction to the technology; including limitations and pitfalls as well as practical considerations with regard to patient preparation and scan acquisition. Through a presentation of recent meta-analyses as well as clinical studies, the role of PET/CT in diagnosing and staging patients with non-small cell lung cancer will be described and discussed.
\end{abstract}

Keywords Non-small cell lung cancer $\cdot$ PET/CT Positron emission tomography . Solitary pulmonary nodule .

Diagnosis $\cdot$ Staging $\cdot$ Diagnostic accuracy $\cdot$ Cost-

effectiveness

\section{Introduction}

In order to improve survival of patients with lung cancer, focus has been on early diagnosis and accurate staging, as the cornerstone for a growing number of therapy options [1]. Treatment options for lung cancer patients are highly

B. M. Fischer $(\varangle) \cdot J$. Mortensen

Department of Clinical Physiology,

Nuclear Medicine and PET, Rigshospitalet, Copenhagen

University Hospital,

Blegdamsvej 9,

2100 Copenhagen, Denmark

e-mail: malene.fischer@rh.regionh.dk

J. Mortensen

e-mail: jann.mortensen@rh.regionh.dk dependent on the stage of the disease, making accurate and fast staging pivotal.

The process of diagnosing lung nodules and staging lung cancer has become increasingly complex, and is best done in multidisciplinary teams including pulmonologist, thoracic surgeons, pathologist, radiologists, and as the use of PET has become more widespread also a nuclear medicine physician. Imaging plays an increasingly important role in the management of cancer patients. Even though imaging technologies only account for a minor fraction of total cancer costs, they have been found to be increasing with at least double the rate of overall costs [2•]. Lung cancer is an illustrative example of this trend: From 1999 to 2006 the total Medicare costs per patient with lung cancer annually increased by $2.6 \%$; in the same period imaging costs more than doubled, with an annual increase by $9.5 \%$. This increase is mainly due to an increase in the use of positron emission tomography (PET); ie, the use of PET had an annual increase by $36 \%$.

The purpose of this review is to describe and discuss the role of PET, more specifically PET/CT, in the discipline of lung cancer diagnosis and staging. The focus of this review will be non-small cell lung cancer (NSCLC). For a recent review on small cell lung cancer please refer to the work of Thomson et al. [3•].

\section{Positron emission tomography}

Positron emission tomography with computed tomography (PET/CT) and the clinical use of this imaging technology has developed rapidly during the last decade. The increase in computer power and not least the development of a hybrid PET/CT scanner has changed the role of PET from a specialized research tool to a widely available clinical 
workhorse. The first PET/CT scanner was introduced in 2000 in the United States, combining the functional information from the PET scanner with anatomical structures obtained by CT [4]. During the last decade approximately 2,000 PET/CT scanners have been installed in the United States (6.5 scanner per million people), 70 in Germany (1.2 scanner per million people), and $350 \mathrm{PET} / \mathrm{CT}$ scanners in Europe as a whole (0.4 scanner per million people) [5•].

$\left[{ }^{18} \mathrm{~F}\right]$-Fluorodeoxyglucose (FDG) is by far the most commonly used PET tracer, exploiting the increased glucose uptake and metabolism in malignant cells [6]. The basis for the usability of FDG over a broad spectrum of different kinds of cancer is the increased expression and activity of glucose transporters as well as an overproduction of glycolytic enzymes in malignant cells [6]. The biodistribution of FDG allows sensitive detection in most organs, except brain and bladder. Isotopes for use in the PET technique decay by positron emission followed by annihilation under emission of two 511-KeV photons (Fig. 1). The PET technology is inherently extremely sensitive; in an experimental set-up we found the detection limit of PET to be in the magnitude of $10^{5}$ to $10^{6}$ malignant cells, less than or equal to a volume of $1 \mathrm{~mm}^{3}$ [7]. However, movement of the positron before annihilation and slight variations in the angle between the two photons limit the spatial resolution of current clinical systems to $4-5 \mathrm{~mm}$ and in general the PET technique has been considered to be less accurate with regard to tumors smaller than $10 \mathrm{~mm}$ [8].

\section{Pitfalls and limitations}

When using PET in the diagnosis of lung cancer a falsepositive rate as high as $20-25 \%$ [9] is reported. This is mainly due to increased uptake of FDG in inflammatory

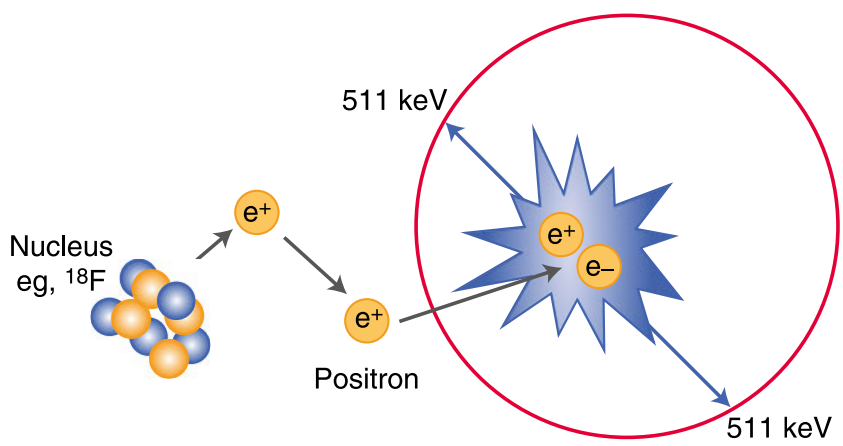

Fig. 1 Positron emission and detection. An isotope (eg, $\left.{ }^{18} \mathrm{~F}\right)$ decays under emission of a positron from the nucleus. In the tissue this positron will meet and annihilate with an electron under emission of two back-to-back photons each of $511 \mathrm{KeV}$. These photons will subsequently be detected by scintillator crystals in the detector ring of the PET scanner. If two photons are detected within a narrow time span (nanoseconds, the so-called coincidence window) they are assumed to be a result of the same annihilation and an event is recorded cells. Major causes of false-positive results in the chest are granulomas, histoplasmosis, tuberculosis, chronic inflammation, sarcoidosis, and Aspergillus infection [10,11]. Also pulmonary embolism or iatrogenic microembolism can cause FDG-uptake mimicking malignancy (but without correlate on CT, Fig. 2) [12]. Iatrogenic procedures might also induce false-positive results: of relevance in lung cancer is placement of chest tubes, percutaneous needle biopsy, mediastinoscopy, radiation pneumonitis, and esophagitis [13]. Finally, focal physiological FDG-uptake, especially in the gastrointestinal tract, can mimic malignancy; likewise can unilateral uptake in striated muscle, brown fat, and atherosclerotic plaques (Fig. 3). Detailed knowledge of patient history and the use of integrated PET/CT (with side-byside reading by nuclear medicine physician and radiologist) can help to distinguish malignant FDG-uptake from uptake due to benign causes and improve specificity. False-negative results are less common and mainly due to small size or well-differentiated malignancies, such as bronchioloalveolar carcinomas and carcinoids [14-16]. Lesions smaller than $5 \mathrm{~mm}$ may be false negative due to the limited spatial resolution and partial volume effects; however, taking respiratory motion into consideration in practice the resolution is approximately $1 \mathrm{~cm} \mathrm{[17].}$

\section{Achieving a high-quality PET/CT examination}

In order to ensure a high diagnostic yield from the PET/CT scan, a number of factors need attention, also from the referring clinician. Most important are blood glucose level which, whenever possible, should be kept under $150 \mathrm{mg} / \mathrm{dL}$, in order to minimize the effects of physiologic activity. Thus, patients should be fasting for at least $4 \mathrm{~h}$, preferably $6 \mathrm{~h}$. As noted above, detailed information on patient history improves the quality of the PET/CT report; especially knowledge about recent biopsy or surgery, chemotherapy, and/or radiotherapy is of importance. If possible a PET/CT scan should be scheduled 1-2 weeks after a biopsy and 26 weeks after surgery depending on the invasiveness and localization of the procedure as well as the clinical indication for performing the PET/CT scan. If the patient has received chemotherapy an interval between the last treatment and the PET/CT scan of approximately 2 weeks will be appropriate in most cases [18].

In the literature, the CT part of the PET/CT scan is often done as a whole-body low-dose scan without intravenous contrast (Table 1) [19]. By doing this it is possible to keep radiation dose from the $\mathrm{CT}$ scan at a minimum and avoid the use of IV contrast, which adds the risk of possible allergic reactions and nephrotoxicity. However, it is our experience and has also been demonstrated by recent studies, that the diagnostic accuracy and clinical value of the PET/CT is 
a
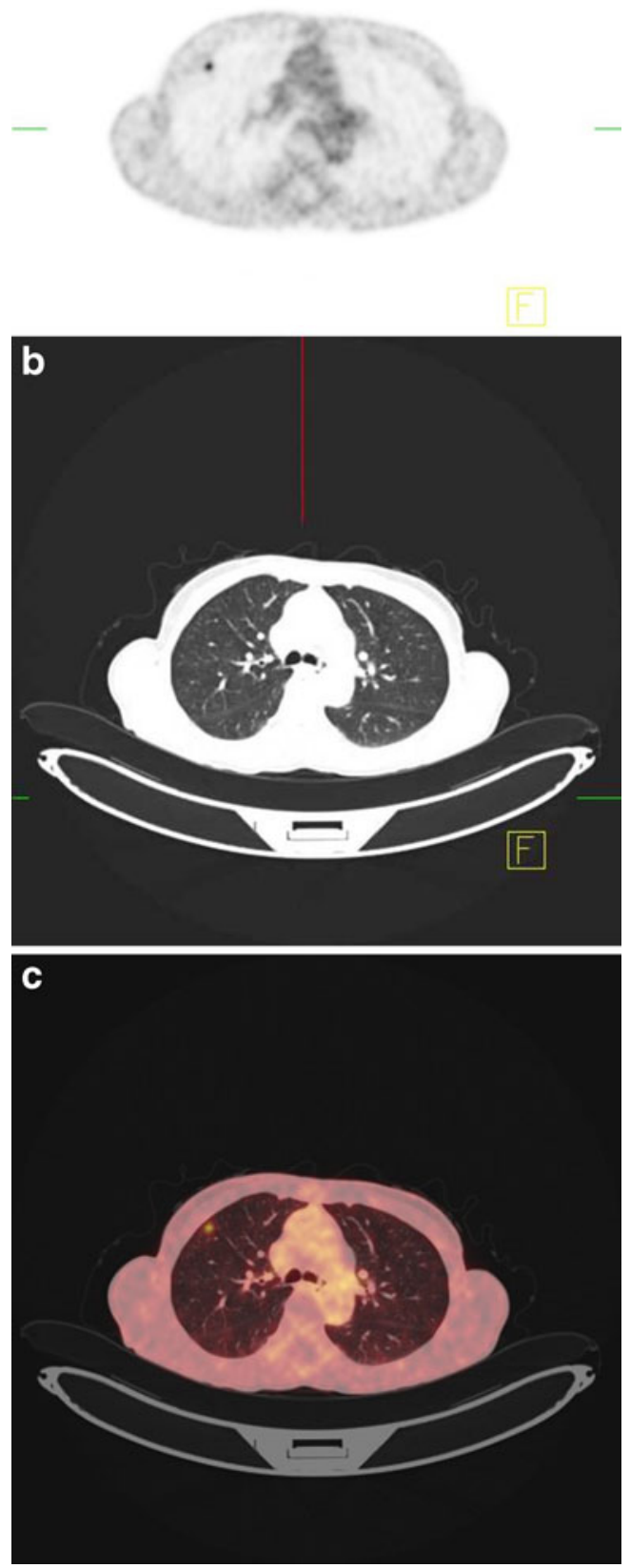

Fig. 2 A 72-year-old woman with known endometrial cancer and two lung metastases, referred for PET/CT in order to exclude further lung metastases prior to stereotactic radiotherapy. a, FDG-PET reveals focal retention lateral in the right lung. $\mathbf{b}$ and $\mathbf{c}$, There was no correlate on $\mathrm{CT}$ and the finding was characterized as a FDG embolus. (Courtesy of Dr. Johan Löfgren)

markedly improved by applying a standard dose contrastenhanced CT, especially with regard to gastrointestinal cancer but also in the staging of lung cancer patients, especially a
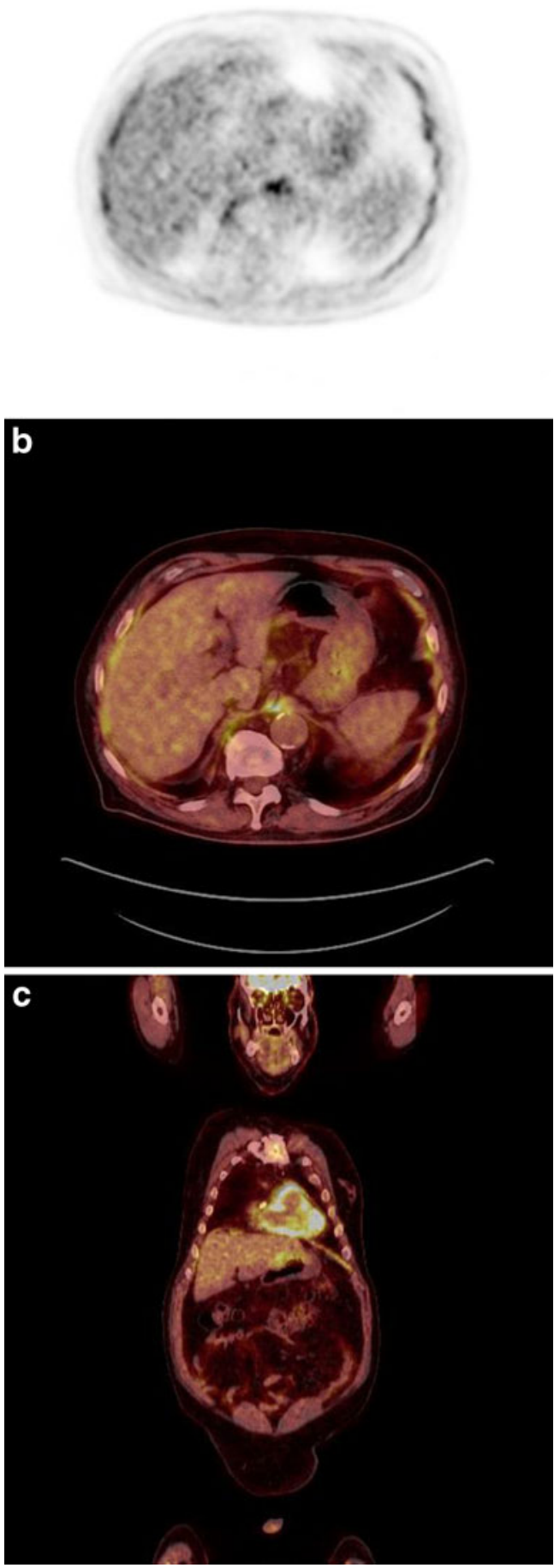

Fig. 3 A 79-year-old man with known asbestosis, but no known malignant diagnosis, referred for PET/CT in order to exclude malignant pleural mesothelioma. a, FDG-PET reveals increased uptake in the thoracic cage and between the spine and liver hilus. $\mathbf{b}$ and $\mathbf{c}$, On the fused images the increased FDG uptake was found to be localized in the striated muscles between the ribs and in the diaphragmatic muscle (auxiliary respiratory muscles) and not in the pleura

with regard to assessment of lymph nodes and precise description of tumor extent [19, 20, 21•]. 
Table 1 Papers comparing the diagnostic accuracy of PET/CT and $\mathrm{CT}$ with regard to solitary pulmonary nodules, published within the last 5 years

\begin{tabular}{|c|c|c|c|c|c|c|}
\hline & \multirow[t]{2}{*}{$N$} & \multicolumn{2}{|l|}{$\mathrm{PET} / \mathrm{CT}$} & \multicolumn{2}{|l|}{$\mathrm{CT}$} & \multirow[t]{2}{*}{ Note } \\
\hline & & $\begin{array}{l}\text { Sensitivity } \\
(95 \% \mathrm{CI})\end{array}$ & $\begin{array}{l}\text { Specificity } \\
(95 \% \mathrm{CI})\end{array}$ & $\begin{array}{l}\text { Sensitivity } \\
(95 \% \mathrm{CI})\end{array}$ & $\begin{array}{l}\text { Specificity } \\
(95 \% \mathrm{CI})\end{array}$ & \\
\hline $\begin{array}{r}\text { Kagna et al. } \\
\text { [26], } 2009\end{array}$ & 93 & $\begin{array}{l}0.94 \\
(0.81-0.98)\end{array}$ & $\begin{array}{l}0.71 \\
(0.58-0.80)\end{array}$ & $\begin{array}{l}0.97 \\
(0.85-0.99)\end{array}$ & $\begin{array}{l}0.48 \\
(0.36-0.61)\end{array}$ & $\begin{array}{l}\text { Retrospective, LD-CT } \\
\text { no contrast }\end{array}$ \\
\hline $\begin{array}{l}\text { Jeong et al. } \\
\text { [27], } 2008\end{array}$ & 100 & $\begin{array}{l}0.88 \\
(0.74-0.95)\end{array}$ & $\begin{array}{l}0.77 \\
(0.65-0.86)\end{array}$ & $\begin{array}{l}0.80 \\
(0.65-0.90)\end{array}$ & $\begin{array}{l}0.67 \\
(0.54-0.77)\end{array}$ & $\begin{array}{l}\text { Retrospective, LD-CT } \\
\text { no contrast }\end{array}$ \\
\hline $\begin{array}{l}\text { Kim et al. } \\
\text { [28], } 2007\end{array}$ & 42 & $\begin{array}{l}0.97 \\
(0.83-0.99)\end{array}$ & $\begin{array}{l}0.85 \\
(0.58-0.96)\end{array}$ & $\begin{array}{l}0.93 \\
(0.78-0.98)\end{array}$ & $\begin{array}{l}0.31 \\
(0.13-0.58)\end{array}$ & $\begin{array}{l}\text { Retrospective, LD-CT } \\
\text { no contrast }\end{array}$ \\
\hline $\begin{array}{l}\text { Yi et al. } \\
\text { [25], } 2006\end{array}$ & 119 & $\begin{array}{l}0.96 \\
(0.89-0.99)\end{array}$ & $\begin{array}{l}0.88 \\
(0.74-0.95)\end{array}$ & $\begin{array}{l}0.81 \\
(0.71-0.88)\end{array}$ & $\begin{array}{l}0.93 \\
(0.80-0.97)\end{array}$ & $\begin{array}{l}\text { Prospective, HD- } \\
\text { CT with contrast }\end{array}$ \\
\hline
\end{tabular}

\begin{abstract}
$H D$-CT high-dose CT; $L D$-CT
low-dose CT
$H D$-CT high-dose CT; $L D$-CT
low-dose CT
\end{abstract}

Diagnosing lung cancer: the solitary pulmonary nodule

A solitary pulmonary nodule (SPN) is defined as a lesion smaller than $3 \mathrm{~cm}$ in diameter completely surrounded by lung tissue [22]. In early systematic reviews comparing the diagnostic value of PET to CT in discriminating malignant from benign pulmonary nodules, PET was found to be highly sensitive (approximately 95\%) but less specific (75-80\%) [23]. A comprehensive meta-analysis has compared the diagnostic accuracy of CT, MRI, FDG-PET, and ${ }^{99 \mathrm{~m}}$ Tc-depreotide single photon emission computed tomography (SPECT) for evaluation of solitary pulmonary nodules [24]. Surprisingly, they did not find any significant difference with regard to sensitivity, specificity, and predictive values between any of the four modalities. However, only the meta-analysis on FDGPET and CT included more than 1000 patients, all CT studies were with dynamic and contrast-enhanced $\mathrm{CT}$ acquisition, and the majority of the PET studies were performed on a single modality PET scanner-not PET/CT. This meta-analysis suggests that the diagnosis of SPN should, to some extent, be guided by local practice and experience.

More recent studies comparing CT and PET/CT (Table 1) have, however, found a significant difference between CT and $\mathrm{PET} / \mathrm{CT}$, in favor of the latter. This difference is seen both with regard to sensitivity and specificity, but especially the difference in specificity decreases when comparing the PET/CT with a high-dose CT with contrast enhancement [25].

The rational choice of diagnostic tests and the consequence of a positive respectively negative outcome depend on the probability of malignancy. In short, patients with a SPN later diagnosed with lung cancer originate from three groups, each representing different pre-test probabilities for cancer: a) patients referred for further examination after presenting with symptoms suspicious for lung cancer (eg, cough, dyspnea, pain, or hemoptysis, or in patients known with another malignancy); b) patients with an incidental finding of a solitary pulmonary nodule (eg, after performing a cardiac CT due to angina or chest X-ray during a health examination); and c) participants in a lung cancer screening trial.

The probability of malignancy in a SPN in each group will also vary significantly dependent on, eg, smoking history, age, and radiological characteristics [29]. The prevalence of malignancy in group a) will typically be $30-70 \%$. In group b) and c) the incidence of SPN will vary dependent on the quality of the CT, field of view, and screening population, but has been reported at approximately 20 $30 \%$, whereas the prevalence of malignancy in these groups will be less than $3 \%[30,31]$. The prevalence or pretest probability of malignancy will significantly influence the predictive value of any diagnostic test. Thus, assessing the pre-test probability of malignancy in a given SPN facilitates interpreting the results of diagnostic imaging (eg, PET) [32] and clinical decision-making.

As prevalence falls, positive predictive value falls with it, whereas negative predictive value rises. In most studies $\mathrm{PET} / \mathrm{CT}$ has a higher negative predictive value compared to CT. The ability of PET to rule out a malignant diagnosis can potentially reduce the number of invasive procedures resulting from, eg, screening trials and auxiliary findings on cardiac CT $[33,34]$. However, in a screening population an increased frequency of small and relatively low-metabolic tumors can be expected, hampering the diagnostic accuracy of the PET technique [35]. This problem can be minimized by combining the information of tumor growth rate (eg, after 3 months) with FDG uptake [31, 36], making PET/ CT a valuable second step test in the diagnosis and followup of indeterminate pulmonary nodules, and also in screening studies (Table 2).

\section{Prognosis and the use of standardized uptake values}

PET can be evaluated visually and/or semiquantitatively by means of the Standardized Uptake Value (SUV). SUV is the activity concentration in the lesion normalized for the 
Table 2 Positive and negative predictive value (PPV and NPV) of PET/CT and CT with regard to solitary pulmonary nodules

\begin{tabular}{|c|c|c|c|c|c|}
\hline & \multirow{2}{*}{$\begin{array}{l}\text { Prevalence of } \\
\text { lung cancer }\end{array}$} & \multicolumn{2}{|l|}{$\mathrm{PET} / \mathrm{CT}$} & \multicolumn{2}{|l|}{ CT } \\
\hline & & $\begin{array}{l}\text { PPV } \\
(95 \% \mathrm{CI})\end{array}$ & $\begin{array}{l}\text { NPV } \\
(95 \% \mathrm{CI})\end{array}$ & $\begin{array}{l}\text { PPV } \\
(95 \% \mathrm{CI})\end{array}$ & $\begin{array}{l}\text { NPV } \\
(95 \% \text { CI })\end{array}$ \\
\hline $\begin{array}{r}\text { Kagna et al. } \\
\text { [26], } 2009\end{array}$ & 0.38 & $\begin{array}{l}0.66 \\
(0.52-0.78)\end{array}$ & $\begin{array}{l}0.95 \\
(0.85-0.99)\end{array}$ & $\begin{array}{l}0.53 \\
(0.41-0.65)\end{array}$ & $\begin{array}{l}0.97 \\
(0.83-0.99)\end{array}$ \\
\hline $\begin{array}{l}\text { Jeong et al. } \\
\text { [27], } 2008\end{array}$ & 0.40 & $\begin{array}{l}0.71 \\
(0.79-0.96)\end{array}$ & $\begin{array}{l}0.90 \\
(0.70-0.91)\end{array}$ & $\begin{array}{l}0.62 \\
(0.48-0.74)\end{array}$ & $\begin{array}{l}0.83 \\
(0.58-0.82)\end{array}$ \\
\hline $\begin{array}{l}\text { Kim et al. } \\
\text { [28], } 2007\end{array}$ & 0.69 & $\begin{array}{l}0.93 \\
(0.79-0.98)\end{array}$ & $\begin{array}{l}0.92 \\
(0.65-0.99)\end{array}$ & $\begin{array}{l}0.75 \\
(0.59-0.86)\end{array}$ & $\begin{array}{l}0.67 \\
(0.30-0.90)\end{array}$ \\
\hline $\begin{array}{l}\text { Yi et al. } \\
\text { [25], } 2006\end{array}$ & 0.66 & $\begin{array}{l}0.94 \\
(0.86-0.97)\end{array}$ & $\begin{array}{l}0.92 \\
(0.79-0.97)\end{array}$ & $\begin{array}{l}0.96 \\
(0.88-0.98)\end{array}$ & $\begin{array}{l}0.71 \\
(0.58-0.82)\end{array}$ \\
\hline
\end{tabular}

injected dose and the weight or body surface area of the patient [37]. Due to high reproducibility of SUV and possible correlation with prognosis [38-40], SUV is often reported in clinical studies and is considered mandatory when using PET for therapy evaluation [41•]. A recent retrospective study on 363 patients in stage I-II, performing preoperative FDG-PET/CT, found that SUV was a predictor of overall survival, but that this correlation was not independent of stage [42]. SUV has also been suggested as a useful tool for separating malignant and benign SPN [43, 44]. The use of SUV is intriguing - captivating the nature of the tumor (malignant or benign) as well as the prognosis of the patient in a single number. However, SUV is highly dependent on a number of factors related to the patient (eg, length of fast, period between injection of FDG and scan time), the type of scanner, and reconstruction algorithm, making it unsuitable for uncritical comparison between different scanners, centers, and time periods. Further, most studies exploring the prognostic value of SUV try to establish an optimal SUV cutoff, based on ROC analysis of own data without performing a validation study in another dataset. This has made comparison between studies difficult and numerous different cutoff values have been suggested [42]. Thus outside clinical trials, SUV should be used with caution, if at all [45].

\section{Staging non-small cell lung cancer}

Non-small cell lung cancer is staged according to the TNM system as initially suggested by Mountain [46], and recently revised by the International Association of Lung Cancer [47, 48]. Only patients with localized disease (TNM stage I-IIB, possibly IIIA) will be candidates for primary curative surgery [49]. For most patients with advanced disease (stage IV) palliative treatment with chemotherapy will be the only option. Thus, in order to allocate the patient to the correct treatment, accurate description of possible 1) distant metastases and 2) mediastinal spread (N) is mandatory, whereas the $\mathrm{T}$ stage at this point will substantially influence the treatment choice only in the case of tumor invasion making resection impossible (Fig. 4).

Primary tumor (T stage)

Single-modality PET is insufficient for an accurate description of T stage, whereas combined PET/CT is significantly more accurate than both PET [50-52] and standard CT (diagnostic quality with intravenous contrast) $[53,54]$. A recent study compared the measurement of primary T1 and T2 NSCLC at $\mathrm{PET} / \mathrm{CT}$ to determine the correlation with histological findings: A high concordance was found between both PET and CT measurements and histological measurements, but PET was better for delineating the tumor in the presence of surrounding atelectasis or consolidation [55].

\section{Mediastinal lymph nodes ( $\mathrm{N}$ stage)}

Mediastinal staging is, in patients without distant metastases, the most significant factor for treatment planning as mediastinal spread (N2-N3 disease) excludes the patient from primary surgery. Initial studies on PET reported very high accuracy with regard to N-staging, significantly higher than the accuracy of CT [56]. In more recent studies this difference seems to narrow down, probably due to the improved quality of CT, but still a staging strategy including $\mathrm{PET} / \mathrm{CT}$ appears more sensitive with regard to mediastinal disease [54, 57]. The European Society of Thoracic Surgery (ESTS) as well as the American College of Chest Physicians (ACCP) has published guidelines for proper preoperative mediastinal staging [58, 59], both including a PET/CT examination. However, it remains more uncertain what consequences should be drawn from the PET/CT result. For example, it has been suggested that mediastinoscopy or other invasive staging can be omitted in cases where the mediastinum is PET-negative [58, 59]. But by doing this, $16 \%$ of the patients will have occult N2 disease $[57,60]$. In 
Fig. 4 A 69-year-old man with a tumor (NSCLC) in the right lung, hilar region, referred for staging by PET/CT. $\mathbf{a}$ and $\mathbf{b}$, FDG-PET shows increased uptake in the primary tumor in the right lung. c, On CT there is an enlarged lymph node anterior to the left main bronchus, but without increased FDG uptake. PET/CT suggested stage T2aNOM0, which was confirmed by EBUS. (Courtesy of Dr. Charlotte B. Christensen)

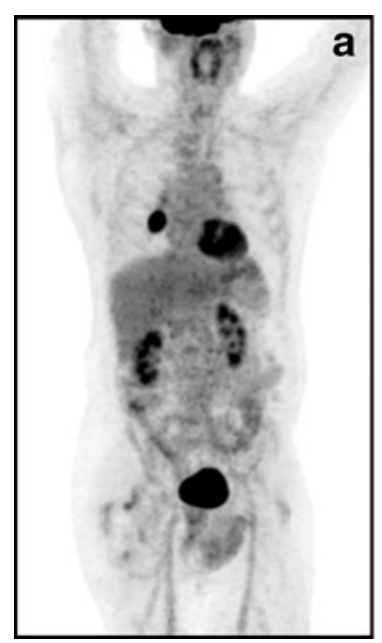

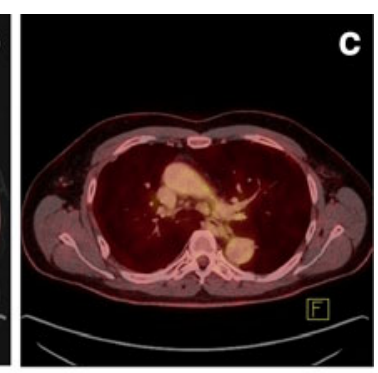

order to avoid under-staging the mediastinum, it is thus recommended that in patients with central tumors, enlarged lymph nodes on CT, and/or N1 disease on PET/CT a confirmatory invasive examination should be performed (Fig. 4). Recent findings also emphasize the use of information provided by both PET and CT (eg, PET/CT cannot exclude nodal disease where nodes are enlarged on CT [>10 mm]), whereas in nodes not significantly enlarged on $\mathrm{CT}$, the false-negative rate of $\mathrm{PET} / \mathrm{CT}$ is below 5\% $[57,61]$.

\section{Distant metastases}

NSCLC most frequently metastasizes to bones, brain, adrenals, and liver and M1 disease is reported in 5-15\% of otherwise operable patients performing PET or PET/CT $[52,56],[62 \bullet]$.

With regard to the bones several studies indicate that PET is as sensitive and more specific than bone scan and CT for detection of bone metastases [63-66]. FDG-PET images tumor cells and not changes in the bone structure respectively metabolism, as is the case with CT and bone scan [67]. Thus PET often can diagnose bone metastasis before they become visible on $\mathrm{CT}$ or bone scan. A bone-seeking tracer for PET $\left({ }^{18}\right.$ F-fluoride, $\left.\mathrm{NaF}\right)$ has become widely available as an alternative to the traditional bone scans. The experience in staging of lung cancer is scarce, but a recent study compared FDGPET/CT with bone scan or ${ }^{18}$ F-fluoride-PET, finding that FDG-PET/CT was superior to both [68]. Thus having performed a FDG-PET/CT for staging neither bone scan nor ${ }^{18} \mathrm{~F}$ fluride PET will be indicated.

PET performs poorly in the detection of brain metastases, mainly due to the high background signal caused by physiologic cerebral FDG uptake. This was confirmed in a recent study comparing cerebral MRI and FDG-PET/CT for diagnosing brain metastasis at initial staging in 104 neurological asymptomatic patients: the sensitivity of PET/CT was $27 \%(95 \% \mathrm{CI}, 13-48 \%)$, whereas due to the relatively low prevalence in this study $(20 \%)$ the negative predictive value reached an acceptable 83\% (95\% CI, 75-89\%) [69]. Thus, in case of neurological symptoms a negative PET/CT scan does not exclude brain metastases.

Indeterminate adrenal masses on $\mathrm{CT}$ are seen in approximately $5-15 \%$ of patients with NSCLC; approximately $60 \%$ represent metastases $[70,71]$. Several studies have shown that PET, and recently PET/CT, is effective in discriminating between malignant and benign adrenal masses [72-75]. PET-negative adrenal lesions will usually not be metastatic; however, isolated PET-positive lesions should be confirmed in order to avoid deeming a patient inoperable on a false-positive basis [76].

No studies specifically address the value of PET in diagnosing hepatic metastases, but successful detection has been reported [9, 14]; however, especially in smaller metastases the sensitivity is hampered by physiologic FDG uptake of the liver.

Pleural effusion and metastases are often found when staging patients with lung cancer. With the new TNM staging system malignant pleural effusion is classified as M1 disease (instead of T4), making correct assessment even more important. It is broadly accepted that PET is inferior to CT in detecting pleural effusion. Some studies have shown that PET might be useful in discriminating between malignant and benign pleural effusion diagnosed by CT [77], but this is still controversial and thoracocentesis should be attempted.

\section{Clinical impact of staging by PET/CT}

The clinical impact of PET/CT can be assessed as the frequency of change in patient management due to information provided by PET/CT. Assigning the overall TNM stage (stage IIV), PET/CT appears to be the most accurate imaging method and is superior to most invasive methods being a "wholebody" examination [53, 54]. Behind the chase for initial correct $\mathrm{T}, \mathrm{N}$, and $\mathrm{M}$ classification resides the wish to avoid futile surgery - ie, performing a thoracotomy in a patient who 
eventually has an early local or distant relapse or in whom surgery results in incomplete resection or resection of a benign nodule $[78,79]$. Two randomized studies have recently demonstrated that preoperative staging with PET/CT significantly reduces the frequency of futile thoracotomies without affecting overall survival $\left[62 \bullet, 80^{\bullet}\right]$. The improvement in preoperative staging is mainly due to increased sensitivity of the PET/ CT strategy and applies to all patients independent of the initial stage at presentation. Specificity of PET/CT is hampered by false-positive findings and hence (solitary) positive foci on PET/CT with potential influence on the choice of treatment need confirmatory biopsy. Even so, the number of work-up procedures in a PET/CT strategy seems to be fewer than or equal to a strategy without PET/CT $[80 \bullet, 81]$.

\section{Considerations on health economy}

The cost effectiveness of stand-alone PET as an adjunct to mediastinoscopy and CT has been examined in several studies during the past 15 years with general findings pointing in a positive direction [82-85]. Only one economic evaluation has been conducted alongside a randomized clinical trial: Verboom et al. [86] reported that the addition of PET to conventional staging was associated with a cost saving of $€ 1,289$ (1999 price level) due to the cost of the scan being more than outweighed by the more precise selection of candidates for thoracotomy. We performed a similar analysis alongside a randomized study on PET/CT [87], reporting an incremental cost of the PET/CTbased regimen at $€ 3,927$. As five PET/CT scans should be performed in order to avoid one futile thoracotomy, the resulting incremental cost effectiveness ratio (ICER) was $€ 19,314$ per avoided futile thoracotomy.

These two analyses differ in several ways. The Dutch study [86] adapts a restricted hospital perspective (ie, from the provider's perspective, including only costs associated with hospital days, thoracotomies, invasive and noninvasive diagnostic tests, and excluding costs associated with comorbidity, chemotherapy, and radiotherapy). In the Danish study [87], a full health care sector perspective was sought and costs were calculated from the payer's perspective using DRG (diagnosis-related group) tariffs. When costs of comorbidity-related hospital services were excluded from the Danish study, the $\mathrm{PET} / \mathrm{CT}$ regimen appeared superior to the conventional staging regimen, saving $€ 899$ per patient.

An attempt to estimate the cost-utility (cost per qualityadjusted life-year, QALY) of staging with PET/CT has recently been performed by a German group [88]. A direct measurement of the quality of life was not attempted; instead a modeling approach was adapted, defining quality of life as 1 for patients alive, 0 in the case of death, and a loss in quality of life due to surgical morbidity of 0.15 QALYs. The group report an ICER pr. QALY of $€ 59,272$ for staging by PET/CT versus CT alone [88, 89], thus substantially higher than the willingness to pay $(€ 34,000)$ suggested by NICE (National Institute for Clinical Excellence, the British Institute for Assessment of Health Technologies) [90].

\section{Conclusions and perspectives}

The role and potential impact of PET/CT in diagnosing and staging patients with non-small cell lung cancer is well established and incorporated in several clinical guidelines and recommendations.

$\mathrm{PET} / \mathrm{CT}$ can differentiate between malignant and benign SPN. This is particularly useful in order to minimize the number of invasive examinations necessary to exclude malignancy in pulmonary nodules found in patients without symptoms. A PET/CT scan, performed with a fully diagnostic, contrastenhanced CT, can accurately stage patients with NSCLC according to the TNM system. It is now documented by two randomized clinical trials that $\mathrm{PET} / \mathrm{CT}$ improves preoperative staging and reduces the number of futile thoracotomies.

$\mathrm{PET} / \mathrm{CT}$ is potentially hampered by a relatively high frequency of false-positive findings; however, both specificity and sensitivity can be increased by detailed knowledge of patient history and side-by-side reading by an experienced radiologist and nuclear medicine physician. However, in the case of solitary PET-positive findings excluding the patient from potentially curative treatment, verification by biopsy should be sought.

Finally, it should be emphasized that PET/CT is not only for diagnosis and staging. It is beyond doubt that the majority of future research on PET/CT and lung cancer will focus on the increasingly important role of PET/CT in especially radiotherapy planning $[91,92 \cdot]$ but also evaluation of treatment with chemotherapy and in the diagnosis of relapse $[41 \cdot 93]$. A carefully performed PET/CT scan can not only assist in diagnosing and staging lung cancer, but also serve as a baseline scan for evaluation during and after chemotherapy as well as in the detection of relapse.

Disclosure No potential conflicts of interest relevant to this article were reported.

\section{References}

Papers of particular interest, published recently, have been highlighted as:

- Of importance

1. Ettinger DS, Akerley W, Bepler G, Blum MG, Chang A, Cheney RT, et al. Non-small cell lung cancer. J Natl Compr Canc Netw. 2010;8(7):740-801. 
2. - Dinan MA, Curtis LH, Hammill BG, Patz EF, Abernethy AP, Shea AM, et al. Changes in the Use and Costs of Diagnostic Imaging Among Medicare Beneficiaries With Cancer, 19992006. JAMA. 2010;303(16):1625-31. Interesting and highly relevant description and discussion of the use and cost of imaging technologies.

3. - Thomson D, Hulse P, Lorigan P, Faivre-Finn C. The role of positron emission tomography in management of small cell lung cancer. Lung Cancer. 2011;73:121-6. New and comprehensive review on the use of PET in small cell lung cancer.

4. Beyer T, Townsend DW, Brun T, Kinahan PE, Charron M, Roddy $\mathrm{R}$, et al. A combined PET/CT scanner for clinical oncology. J Nucl Med. 2000;41(8):1369-79.

5. - Buck AK, Herrmann K, Stargardt T, Dechow T, Krause BJ, Schreyogg J. Economic Evaluation of PET and PET/CT in Oncology: Evidence and Methodologic Approaches. J Nucl Med. 2010;51(3):401-12. An educative review of different methods and problems in the evaluation of PET/CT from an economical perspective.

6. Pauwels EKJ, Sturm EJC, Bombardieri E, Cleton FJ, Stokkel MPM. Positron-emission tomography with $\left[{ }^{18} \mathrm{~F}\right]$ fluorodeoxyglucose. Part I. Biochemical uptake mechanism and its implication for clinical studies. J Cancer Res Clin Oncol. 2000;126:549-59.

7. Fischer B, Olsen M, Ley C, Klausen T, Mortensen J, Højgaard L, et al. How few cancer cells can be detected by positron emission tomography? A frequent question addressed by an in vitro study. Eur J Nucl Med Mol Imaging. 2006;33(6):697-702.

8. Nomori H, Watanabe K, Ohtsuka T, Naruke T, Suemasu K, Uno K. Evaluation of F-18 fluorodeoxyglucose (FDG) PET scanning for pulmonary nodules less than $3 \mathrm{~cm}$ in diameter, with special reference to the CT images. Lung Cancer. 2004;45(1):19-27.

9. Stroobants S, Verschakelen J, Vansteenkiste J. Value of FDG-PET in the management of non-small cell lung cancer. Eur J Radiol. 2003;45:49-59.

10. Fischer BM, Mortensen J. The future in diagnosis and staging of lung cancer: positron emission tomography. Respiration. 2006;73:26776.

11. Baxter CG, Bishop P, Low SE, Baiden-Amissah K, Denning DW. Primary aspergillosis: an alternative diagnosis to lung cancer after positive ${ }^{18} \mathrm{~F}$-FDG positron emission tomography. Thorax. 2011;66 (7):638-40.

12. Schreiter N, Nogami M, Buchert R, et al. Pulmonary FDG uptake without a CT counterpart-pitfall in interpreting PET/CT images. Acta Radiol. 2011;52(5):513-5.

13. Truong MT, Erasmus JJ, Macapinlac HA, Marom EM, Mawlawi $\mathrm{O}$, Gladish GW, et al. Integrated positron emission tomography/ computed tomography in patients with non-small cell lung cancer: normal variants and pitfalls. J Comput Assist Tomogr. 2005;29 (2):205-9.

14. Ho Shon I, O’Doherty MJ, Maisey MN. Positron emission tomography in lung cancer. Semin Nucl Med. 2002;XXXII(4):240-70.

15. Marom EM, Sarvis S, Herndon II JE, Patz Jr EF. T1 lung cancers: sensitivity of diagnosis with fluorodeoxyglucose PET. Radiology. 2002;223:453-9.

16. Higashi K, Matsunari I, Ueda Y, Ikeda R, Guo J, Oguchi M, et al. Value of whole-body FDG PET in management of lung cancer. Ann Nucl Med. 2003;17(1):1-14.

17. Divisi D, Di Tommaso S, Di Leonardo G, et al. 18-fluorine fluorodeoxyglucose positron emission tomography with computerized tomography versus computerized tomography alone for the management of solitary lung nodules with diameters inferior to $1.5 \mathrm{~cm}$. Thorac Cardiovasc Surg. 2010;58(7):4226.

18. Lin EC, Alavi A. Patient preparation. In: Lin EC, Alavi A, editors. PET and PET/CT. A clinical guide. 2nd ed. New york: Thieme; 2009. p. 33-7.
19. Pfannenberg AC, Aschoff P, Brechtel K. Value of contrast-enhanced multiphase CT in combined PET/CT protocols for oncological imaging. Br J Radiol. 2007;80:437-45.

20. Pfannenberg AC, Aschoff P, Brechtel K, et al. Low dose nonenhanced CT versus standard dose contrast-enhanced CT in combined PET/CT protocols for staging and therapy planning in nonsmall cell lung cancer. Eur J Nucl Med Mol Imaging. 2007;34:36-44.

21. Cronin CG, Prakash P, Blake MA. Oral and IV contrast agents for the CT portion of PET/CT. AJR. 2010;195:W5-W13. An educative review on the consequences of using (or not using) contrast agents in PET/CT.

22. Wahidi MM, Govert JA, Goudar RK, Gould MK, McCrory DC. Evidence for the treatment of patients with pulmonary nodules: when is it lung cancer?*. Chest. 2007;132(3 suppl):94S-107S.

23. Gould MK, Maclean CC, Kuschner WG, Rydzak CE, Owens DK. Accuracy of positron emission tomography for diagnosis of pulmonary nodules and mass lesions: a meta-analysis. JAMA. 2001;285(7):914-24.

24. Cronin P, Dwamena BA, Kelly AM, Carlos RC. Solitary pulmonary nodules: meta-analytic comparison of cross-sectional imaging modalities for diagnosis of malignancy. Radiology. 2008;246 (3):772-82.

25. Yi CA, Lee KS, Kim BT, Choi JY, Kwon OJ, Kim H, et al. Tissue characterization of solitary pulmonary nodule: comparative study between helical dynamic CT and integrated PET/CT. J Nucl Med. 2006;47(3):443-50.

26. Kagna O, Solomonov A, Keidar Z, Bar-Shalom R, Fruchter O, Yigla $\mathrm{M}$, et al. The value of FDG-PET/CT in assessing single pulmonary nodules in patients at high risk of lung cancer. Eur J Nucl Med Mol Imaging. 2009;36(6):997-1004.

27. Jeong SY, Lee KS, Shin KM, Bae YA, Kim BT, Choe BK, et al. Efficacy of PET/CT in the characterization of solid or partly solid solitary pulmonary nodules. Lung Cancer. 2008;61(2):186-94.

28. Kim SK, Allen-Auerbach M, Goldin J, Fueger BJ, Dahlbom M, Brown M, et al. Accuracy of PET/CT in characterization of solitary pulmonary lesions. J Nucl Med. 2007;48(2):214-20.

29. Gould MK, Fletcher J, Iannettoni MD, Lynch WR, Midthun DE, Naidich DP, et al. Evaluation of patients with pulmonary nodules: when is it lung cancer?*. Chest. 2007;132(3 suppl):108S-30S.

30. Pedersen JH, Ashraf H, Dirksen A. The danish randomized lung cancer CT screening trial-overall design and results of the prevalence round. J Thorac Onc. 2009;4(5):608-14.

31. Ashraf H, Dirksen A, Loft A, Bertelsen AK, Bach KS, Hansen H, et al. Combined use of positron emission tomography and volume doubling time in lung cancer screening with low-dose CT scanning. Thorax. 2011;66(4):315-9.

32. Gould MK, Ananth L, Barnett PG. A clinical model to estimate the pretest probability of lung cancer in patients with solitary pulmonary nodules*. Chest. 2007;131(2):383-8.

33. Aglan I, Jodocy D, Hiehs S, Soegner P, Frank R, Haberfellner B, et al. Clinical relevance and scope of accidental extracoronary findings in coronary computed tomography angiography: a cardiac versus thoracic FOV study. Eur J Radiol. 2010;74(1):166-74.

34. Pastorino U, Bellomi M, Landoni C, De Fiori E, Arnaldi P, Picchio $\mathrm{M}$, et al. Early lung cancer detection with spiral CT and positron emission tomography in heavy smokers: 2 year-results. Lancet. 2003;362:593-7.

35. Lindell RM, Hartman TE, Swensen SJ, Jett JR, Midthun DE, Nathan MA, et al. Lung cancer screening experience: a retrospective review of PET in 22 non-small cell lung carcinomas detected on screening chest CT in a high-risk population. AJR. 2005;185 (1):126-31.

36. Bastarrika G, Garcia-Velloso MJ, Lozano MD, Montes U, Torre W, Spiteri N, et al. Early lung cancer detection using spiral computed tomography and positron emission tomography. Am J Respir Crit Care Med. 2005;171(12):1378-83. 
37. Thie J. Understanding the standardized uptake value, its methods, and implications for usage. J Nucl Med. 2004;45(9):1431-4.

38. Paesmans M, Berghmans T, Dusart M, et al. Primary tumor standardized uptake value measured on fluorodeoxyglucose positron emission tomography is of prognostic value for survival in nonsmall cell lung cancer: update of a systematic review and metaanalysis by the European Lung Cancer Working Party for the International Association for the Study of Lung Cancer Staging Project. J Thorac Oncol. 2010;5(5):612-9.

39. Weber WA, Ziegler SI, Thödtmann R, Hanauske AR, Schwaiger $\mathrm{M}$. Repoducibility of metabolic measurements in malignant tumors using FDG PET. J Nucl Med. 1999;40:1771-7.

40. Cerfolio RJ, Bryant AS, Buddhiwardhan O, Bartolucci AA. The maximum standardized uptake values on positron emission tomography of a non-small cell lung cancer predict stage, recurrence, and survival. J Thorac Cardiovasc Surg. 2005;130:151-9.

41. - Wahl RL, Jacene H, Kasamon Y, Lodge MA. From RECIST to PERCIST: evolving considerations for PET response criteria in solid tumors. J Nucl Med. 2009;50 Suppl 1:122S-50S. Comprehensive review of the possibilities and challenges for the use of PET in response evaluation.

42. Agarwal M, Brahmanday G, Bajaj SK, et al. Revisiting the prognostic value of preoperative ${ }^{18} \mathrm{~F}$-fluoro-2-deoxyglucose positron emission tomography (PET) in early-stage (I \& II) non-small cell lung cancers. Eur J Nucl Med Mol Imaging. 2010;37:691-8.

43. Grgic A, Yüksel Y, Gröschel A, et al. Risk stratification of solitary pulmonary nodules by means of PET using (18)F-fluorodeoxyglucose and SUV quantification. Eur J Nucl Med Mol Imaging. 2010;37(6):1087-94.

44. Kim SC, Machac J, Krynyckyi BR, et al. Fluoro-deoxy-glucose positron emission tomography for evaluation of indeterminate lung nodules: assigning a probability of malignancy may be preferable to binary readings. Ann Nucl Med. 2008;22(3):165-70.

45. Hashimoto Y, Tsujikawa T, Kondo C, et al. Accuracy of PET for diagnosis of solid pulmonary lesions with ${ }^{18} \mathrm{~F}$-FDG uptake below the standardized uptake value of 2.5. J Nucl Med. 2006;47(3):42631.

46. Mountain CF. Revisions in the international system for staging lung cancer. Chest. 1997;111(6):1710-7.

47. Detterbeck FCM, Boffa DJM, Tanoue LTM. The new lung cancer staging system. Chest. 2009;136(1):260-71.

48. Goldstraw PF, Crowley JP, Chansky KM, Giroux DJM, Groome PAP, Rami-Porta RM, et al. The IASLC lung cancer staging project: proposals for the revision of the TNM stage groupings in the forthcoming (Seventh) edition of the TNM classification of malignant tumours. J Thorac Onc. 2007;2(8):706-14.

49. National comprehensive cancer network. NCCN clinical practice guidelines in oncology. Non-small cell lung cancer. www ncen com 2011 Available from: URL: www.ncen.org

50. Halpern BS, Schiepers C, Weber WA, Crawford TL, Fueger BJ, Phelps ME, et al. Presurgical staging of non-small cell lung cancer: positron emission tomography, integrated positron emission tomography/CT, and software image fusion. Chest. 2005;128(4):228997.

51. Cerfolio RJ, Ojha B, Bryant AS, Raghuveer V, Mountz JM, Bartolucci AA. The accuracy of integrated PET-CT compared with dedicated PET alone for the staging of patients with nonsmall cell lung cancer. Ann Thorac Surg. 2004;78:1017-23.

52. Lardinois D, Weder W, Hany T, Kamel EM, Korom S, Seifert B, et al. Staging of non-small-cell lung cancer with integrated positronemission-tomography and computed tomography. N Engl J Med. 2003;348:2500-7.

53. Antoch G, Stattaus J, Nemat AT, Marnitz S, Beyer T, et al. Nonsmall cell lung cancer: dual-modality $\mathrm{PET} / \mathrm{CT}$ in preoperative staging. Radiology. 2003;229:526-33.
54. De Wever W, Ceyssens S, Mortelmans L, Stroobants S, Marchal G, Bogaert J, et al. Additional value of PET-CT in the staging of lung cancer: comparison with CT alone, PET alone and visual correlation of PET and CT. Eur Radiol. 2007;17:23-32.

55. Pawaroo D, Cummings NM, Musonda P, et al CNMPea. Non-small cell lung carcinoma: accuracy of PET/CT in determining the size of T1 and T2 tumors. AJR Am J Roentgenol. 2011;196(5):1176-81.

56. Reed CE, Harpole DH, Posther K, Woolson SL, Downey RJ, et al. Results of the american college of surgeons oncology group Z0050 trial: the utility of positrone emission tomography in staging potentially operable non-small cell lung cancer. J Thorac Cardiovasc Surg. 2003;126(6):1943-51.

57. Fischer BM, Mortensen J, Hansen H, Vilmann P, Larsen SS, Loft A, et al. Multimodality approach to mediastinal staging in nonsmall cell lung cancer. Faults and benefits of PET-CT: a randomised trial. Thorax. 2011;66(4):294-300.

58. De Leyn P, Lardinois D, Van Schil P, Rami-Porta R, Passlick B, Zielinski $\mathrm{M}$, et al. ESTS guidelines for preoperative lymph node staging for non-small cell lung cancer. Eur J Cardio Thorac Surg. 2007;32:1-8.

59. Detterbeck F, Jantz MA, Wallace M, Vansteenkiste J, Silvestri G. Invasive mediastinal staging of lung cancer. ACCP evidence-based clinical practice guidelines (2nd edition). Chest. 2007;132:202s$20 \mathrm{~s}$.

60. Al-Sarraf N, Aziz R, Gately K, Lucey J, Wilson L, McGovern E, et al. Pattern and predictors of occult mediastinal lymph node involvement in non-small cell lung cancer patients with negative mediastinal uptake on positron emission tomography. Eur J Cardio Thorac Surg. 2008;33:104-9.

61. Navani N, Spiro SG. PET scanning is important in lung cancer; but it has its limitations. Respirology. 2010;15:1149-51.

62. - Fischer B, Lassen U, Mortensen J, Larsen S, Loft A, Bertelsen A, et al. Preoperative staging of lung cancer with combined PET-CT. N Engl J Med. 2009;361(1):32-9. First published randomized study on preoperative staging of NSCLC with PET/CT.

63. Hsia TC, Shen YY, Yen RF, Kao CH, Changlai SP. Comparing whole body ${ }^{18} \mathrm{~F}$-2-deoxyglucose positron emission tomography and technetium-99m methylene diophosphate bone scan to detect bone metastases in patients with non-small cell lung cancer. Neoplasma. 2002;49(4):267-71.

64. Gayed I, Vu T, Johnson M, Macapinlac H, Podoloff D. Comparison of bone and 2-deoxy-2-[ $\left.{ }^{18} \mathrm{~F}\right]$ fluoro-D-glucose positron emission tomography in the evaluation of bony metastases in lung cancer. Mol Imaging Biol. 2003;5(1):26-31.

65. Cheran SK, Herndon JE, Patz Jr EF. Comparison of whole-body FDG-PET to bone scan for detection of bone metastases in patients with a new diagnosis of lung cancer. Lung Cancer. 2004;44 (3):317-25.

66. Song JW, Oh YM, Shim TS, Kim WS, Ryu JS, Choi CM. Efficacy comparison between ${ }^{18} \mathrm{~F}$-FDG PET/CT and bone scintigraphy in detecting bony metastases of non-small-cell lung cancer. Lung Cancer. 2009;65(3):333-8.

67. Fischer BM, Mortensen J, Langer SW, Loft A, Berthelsen $\mathrm{AK}$, Petersen BL, et al. A prospective study of $\mathrm{PET} / \mathrm{CT}$ in initial staging of small-cell lung cancer: comparison with CT, bone scintigraphy and bone marrow analysis. Ann Oncol. 2007;18 (2):338-45

68. Krüger S, Buck AK, Mottaghy FM, et al. Detection of bone metastases in patients with lung cancer: $99 \mathrm{mTc}-\mathrm{MDP}$ planar bone scintigraphy, ${ }^{18} \mathrm{~F}$-fluoride PET or ${ }^{18} \mathrm{~F}$-FDG PET/CT. Eur J Nucl Med Mol Imaging. 2009;36(11):1807-12.

69. Krüger S, Mottaghy FM, Buck AK, et al. Brain metastasis in lung cancer. Comparison of cerebral MRI and ${ }^{18} \mathrm{~F}-\mathrm{FDG}-\mathrm{PET} / \mathrm{CT}$ for diagnosis in the initial staging. Nuklearmedizin. 2011;50(3):1016. 
70. Chapman GS, Kumar D, Redmond 3rd J, Munderloh SH, Gandara DR. Upper abdominal computerized tomography scanning in staging non-small cell lung carcinoma. Cancer. 1984;54 (8):1541-3.

71. Ettinghausen SE, Burt ME. Prospective evaluation of unilateral adrenal masses in patients with operable non-small-cell lung cancer. J Clin Oncol. 1991;9:1462-6.

72. Erasmus JJ, Patz Jr EF, McAdams HP, Murray JG, Herndon J, Coleman RE, et al. Evaluation of adrenal masses in patients with bronchogenic carcinoma using ${ }^{18} \mathrm{~F}$-fluorodeoxyglucose positron emission tomography. AJR. 1997;168:1357-60.

73. Kumar R, Xiu Y, Yu JQ, Takalkar A, El Haddad G, Potenta S, et al. ${ }^{18}$ F-FDG PET in evaluation of adrenal lesions in patients with lung cancer. J Nucl Med. 2004;45(12):2058-62.

74. Bury T, Dowlati A, Paulus P, Corhay JL, Hustinx R, Ghaye B, et al. Whole-body ${ }^{18} \mathrm{FDG}$ positron emission tomography in the staging of non-small cell lung cancer. Eur Respir J. 1997;10:2529-34.

75. Metser U, Miller E, Lerman H, Lievshitz G, Avital S, Even-Sapir E. ${ }^{18} \mathrm{~F}$-FDG PET/CT in the evaluation of adrenal masses. J Nucl Med. 2006;47(1):32-7.

76. Ozcan KP, Kara T, Kara GG, et al. The role of fluorodeoxyglucosepositron emission tomography/computed tomography in differentiating between benign and malignant adrenal lesions. Nucl Med Commun. 2011;32(2):106-12.

77. Toaff JS, Metser U, Gottfried M, Gur O, Deeb ME, Lievshitz G, et al. Differentiation between malignant and benign pleural effusion in patients with extra-pleural primary malignancies. Assessment with positron emission tomography-computed tomography. Investig Radiol. 2005;40(4):204-9.

78. van Tinteren H, Hoekstra OS, Smit EF, van den Bergh J, Schreurs AJM, et al. Effectiveness of positron emission tomography in the preoperative assessment of patients with suspected non-small-cell lung cancer: The PLUS multicentre randomised trial. Lancet. 2002;359:1388-92.

79. Swensen SJ, Brown LR, Colby TV, Weaver AL, Midthun DE. Lung nodule enhancement at CT: prospective findings. Radiology. 1996;201:447-55.

80. • Maziak DE, Darling GE, Inculet RI, Gulenchyn KY, Driedger AA, Ung YC, et al. Positron emission tomography in staging early lung cancer. A randomized trial. Ann Intern Med. 2009;151:221-8. Together with reference 62, the first randomized trial on the use of PET/CT for staging NSCLC.

81. Herder GJ, Kramer H, Hoekstra OS, Smit EF, Pruim J, van Tinteren $\mathrm{H}$, et al. Traditional versus up-front $\left[{ }^{18} \mathrm{~F}\right]$ fluorodeoxyglucosepositron emission tomography staging of non-small-cell lung cancer: a Dutch cooperative randomized study. J Clin Oncol. 2006;24 (12):1800-6.
82. Dietlein M, Weber K, Gandjour A, Moka D, Theissen P, Lauterbach $\mathrm{KW}$, et al. Cost-effectiveness of FDG-PET for the management of potentially operable non-small cell lung cancer: priority for a PETbased strategy after nodal-negative CT results. Eur J Nucl Med. 2000;27(11):1598-609.

83. Alzahouri K, Lejeune C, Woronoff-Lemsi MC, Arveux P, Guillemin F. Cost-effectiveness analysis of strategies introducing FDG-PET into the mediastinal staging of non-small-cell lung cancer from the French healthcare system perspective. Clin Radiol. 2005;60(4):479 92.

84. Nguyen VH, Peloquin S, Lacasse Y. Cost-effectiveness of positron emission tomography for the management of potentially operable non-small cell lung cancer in Quebec. Can Respir J. 2005;12 (1):19-25.

85. Bird A, Norman R, Goodall S. Economic evaluation of positron emission tomography (PET) in non-small cell lung cancer (NSCLC). Sidney: CHERE; 2007.

86. Verboom P, Tinteren H, Hoekstra O, Smit E, Bergh J, Schreurs A, et al. Cost-effectiveness of FDG-PET in staging non-small cell lung cancer: the PLUS study. Eur J Nucl Med Mol Imaging. 2003;30(11):1444-9.

87. Søgaard R, Fischer B, Mortensen J, Højgaard L, Lassen U. Preoperative staging of lung cancer with PET/CT: cost-effectiveness evaluation alongside a randomized controlled trial. Eur J Nucl Med Mol Imaging. 2011;38:802-9.

88. Schreyogg J, Weller J, Stargardt T, Herrmann K, Bluemel C, Dechow $\mathrm{T}$, et al. Cost-effectiveness of hybrid PET/CT for staging of non-small cell lung cancer. J Nucl Med. 2010;51 (11):1668-75.

89. Hicks RJ, Borland J. Are health economics making us sick? J Nucl Med. 2010;51(11):1665-7.

90. National Institute of Clinical Excellence. Guide to the methods of technology appraisal (reference N0515). London: NICE; 2004.

91. Aristei C, Falcinelli L, Palumbo B, Tarducci R. PET and PET/CT in radiation treatment planning for lung cancer. Expert Rev Anticancer Ther. 2010;10(4):571-84.

92. - Pommier P, Touboul E, Chabaud S, Dussart S, Le Pechoux C, Giammarile F, et al. Impact of ${ }^{18} \mathrm{~F}$-FDG PET on treatment strategy and $3 \mathrm{D}$ radiotherapy planning in non-small cell lung cancer: a prospective multicenter study. Am J Roentgenol. 2010;195 (2):350-5. One of the few well-conducted prospective trials on the use of PET/CT in radiotherapy planning in NSCLC.

93. Shankar LK, Hoffman JM, Bacharach S, Graham MM, Karp J, Lammertsma AA, et al. Consensus recommendations for the use of ${ }^{18} \mathrm{~F}$-FDG PET as an indicator of therapeutic response in patients in national cancer institute trials. J Nucl Med. 2006;47 (6):1059-66. 